\title{
Challenging times for competition on the automotive market. The case of European Union and Romania
}

\author{
Liviana Andreea Nimineț, "Vasile Alecsandri” University of Bacau, Romania
}

\begin{abstract}
The article deals with one of the most important sectors in the European Union, the automotive sector seen from the economic as well as from the industrial perspective. As the economic efficiency is usually measured in competition parameters an important part is dedicated to the competition on the motor vehicle market in and outside the European Union, on the Global market. One of the most important process in auto market field is also brought to attention. Furthermore the evolution of automotive market in the European Union and Romania during the economic crisis are analyzed using clearing figures .
\end{abstract}

\section{Keywords}

Competition, European Union, automotive market,

\section{JEL Codes: L62, L53, L26}

\section{Introduction}

One of the key economic and industrial sectors in Europe is the automotive sector (motor vehicle sector). Its importance derives from its linkages within the domestic and international economy and its complex value chain. The automotive sector has a turnover of over $€ 780$ billion. Value added in the automotive sector amounts to around $€ 140$ billion, representing about $8 \%$ of European manufacturing value added. It directly employs more than 2 million people and is responsible in total for more than 12 million jobs across Europe, which is equivalent to about $5.5 \%$ of employment in the EU- $27^{1}$.

There is something special about the EU, and this special thing is the Common market. The existence of this kind of large home market is a major competitive advantage for European manufacturers. Despite this important advantage, growth in mature Western European markets has been broadly flat in the recent years. This market growth and the market itself collapsed in late 2008 due to deepest economic recession in the post-war era. The visible slowing in the decline and recovery of sorts as of the second quarter of 2009 is mostly due to the introduction of scrapping schemes in 12 Member States, with highest incentives and most spectacular results in Germany.

The industry recovery is forecast to be sluggish and to occur at earliest in second-half of 2010 with most of the projected future increases in vehicle consumption due to come from emerging markets (China, India, Russia), where European manufacturers have already a significant presence ${ }^{2}$.

The global motor vehicles market is set to significantly grow in the long term. The estimates are that the global vehicle park will increase from the current 800 million vehicles to

\footnotetext{
1 Commission of the European Communities, European Industry in a changing world, Updated sectorial 2009, Brussels, 30.7.2009 SEC(2009) 1111 final

${ }^{2}$ For further details, See ibidem
} 
between 2 billion and 3.5 billion by 2035, mainly in the market segment of smaller and lowbudget cars. In principle, European manufacturers are well placed to take advantage of this market opportunity and Community trade policy plays a supportive role in terms of enabling fair market access.

\section{CARS 21}

The Commission's modern industrial policy implies the CARS 21 (Competitive Automotive Regulatory System for the 21st century) process, which was originally launched in 2005. This process aims to make recommendations for the short-, medium-, and long-term public policy and regulatory framework of the European automotive industry. This framework enhances global competitiveness and employment, while sustaining further progress in safety and environmental performance at a price affordable to the consumer. The creation of stimulating framework conditions take full account of business realities. In the light of the current overall downturn of the global economic environment and the consequent negative effect on consumer confidence this task becomes even more important. The ongoing credit crisis has reached the mainstream sectors of the economy and is having a highly detrimental impact on the vehicle market. Why this strong effect? First of all because the motor vehicles are one of the most important consumer goods in terms of total household expenditure and secondly because the demand for cars is highly correlated with the general business cycle. The current economic situation is therefore having an adverse impact on the sales of new vehicles in the European Union.

The vehicle industry operates world-wide and is one of the drivers of globalization, characterized by the rapid opening of global markets and the ensuing increase and diversity in the movement of capital. The ongoing technological revolution is transforming the automotive industry from a traditional manufacturing-based sector into an increasingly knowledge-based one. Domestically, the vehicle industry is taking important and often difficult steps to optimize its cost-base and production processes raising fears related to restructuring and relocation.

These factors combined with the need to protect the natural environment, safeguard human health and lives and operate in a high oil price environment have created a situation where industry faces new challenges, responsibilities and opportunities which could alter both the industry and its products.

The policy interactions with industry should seek to improve the framework conditions for vehicle production and carefully analyze the cost and competitiveness impacts of future regulatory activity. The Commission believes that public policy should be predictable while correctly reflecting the increasingly complex demands of society and anticipating trends in world markets. In line with the Better Regulation initiative the Commission initiated a comprehensive automotive-related regulatory and policy review by setting up the CARS 21 High Level Group, which brought together all the main stakeholders to advise the Commission on future policy options .

\section{Competition on the European auto market}

The consolidation which occurred in the global automotive industry over the past few decades is now facing a significant decline in real prices for new motor vehicles, successful new entries, significant fluctuations in market shares, increased consumer choice within the various market segments combined with shortening of model life-cycles are evidence of a generally dynamic competitive environment. Competitive pressure can be expected to increase further as car manufacturers from emerging countries enlarge their presence on the EU markets. 
An analyze of the European motor vehicle market must be global and here global means, taking into account the recent difficulties experienced by the main American manufacturers because they have a substantial presence in the European market. These difficulties resulted in the sale of Jaguar and Land Rover to Tata Motors. The situation in the US further deteriorated culminating in Chrysler and General Motors undergoing court-supervised bankruptcy with ripple effects on the European markets. While Fiat established truly global presence by alliance with Chrysler, European subsidiaries of General Motors will be acquired by new investors - likely outside by the EU. One of the drivers of further consolidation and

new alliances will be linked to overcapacity and a price competitive market, which is likely to lead to as much cost optimization as possible.

Generally, European manufacturers are doing better than their US competitors, but externally, they face tough competition from Japan and South Korea. Europe's competitiveness as a production location is being threatened by other areas, which are catching up in terms of the supply of educated labour and have fewer restrictions on its flexible use. There has been a rapid build-up of capacity in the emerging Asian and Eastern European markets (Turkey, Slovakia, the Czech Republic, Poland, Romania), which combined with a world-wide drop in

demand as from late 2008 may lead to world over-capacity and stimulate price competition. EU producers are not particularly well equipped for price competition and they tend to position their exports in the premium segments. This poses real strategic challenges for the established car makers.

It is extremely important, when analyzing the automotive industry, that we do not view it as a uniform whole because different producers and brands have different histories and legacies, can compete in different market segments and often face different challenges. Generally, however, many of these structural problems are related to comparatively low productivity levels, high labour costs and labour market regulations, high fixed costs and overcapacity. These conditions have now been aggravated by the sharp decline in demand.

Recent record prices in global commodity markets, combined with aggressive price

competition among manufacturers, have led many automotive companies to focus on their long term competitiveness by reducing costs and improving internal efficiency. The challenges of a more aggressive international competition will be greater in the longer term. It is important that industry in Europe is able to draw on its competitive advantages, which are likely to be in the form of high value added, qualitatively advanced products and services requiring the efficient use of available resources, and a highly educated labour force.

When discussing the vulnerability to the financial crisis a very important role has the general access to credit, as between $60 \%$ and $80 \%$ of new private cars in Europe are purchased on the basis of credit financing (often involving automotive companies themselves). Tightening credit conditions combined with their impact on asset prices (particularly house prices, significantly affecting the consumers' perception of wealth) and the uncertainty created by the global economic environment has translated into difficult access to credit and low consumer confidence, which in turn has a highly detrimental impact on the vehicle market. The current economic situation is therefore having an adverse impact on the sales of new vehicles in Europe.

\section{Auto market in Romania during the economic crisis}

Let us move our attention now from the more general case of European car market to a more particular one, that is the automotive Romanian market in time of crisis.

APIA (Association of Car Producers and Importers) admits that 2009 was the "nightmare year for auto market" as 38 car dealers declared the insolvency. These 38 represent almost $10 \%$ of a total of 400 , but the bad news is that the market is in a continuous contraction and the after sales are also going down. In 2005 the sales reached a boom with a record volume 
of 256000 cars sold. 2006 brought a $16 \%$ raise (to 297000 units) and 2007 a $23 \%$ raise (366000 units). These growth determined many investors to enter the auto retail and invest in show rooms that most of the times did not have the after sales services. This tendency continued beyond 2007 as in 200915 more dealerships and for 2010 other 20 were scheduled. In real terms, new car sales in Romania drive down by $52 \%$ in 2009 , to 130,193 units, from 270,899 units in 2008, according to data of the Association of Car Producers and Importers (APIA). As many as 91,457 cars were imported in 2009 and 38,736 units were produced by the largest local automaker Dacia . In 2008, there were counted 188,954 imported cars and 81,945 vehicles produced locally. Dacia was the best selling brand in 2009 , with a market share of 30 percent. It was followed by Hyundai (with 10,798 units sold corresponding to an 8.3 percent market share), Volkswagen (with 9,441 cars sold and a 7.3 percent market share) and Renault (with a 6.9 market share and 8,934 units sold). Skoda sold 8,857 cars last year and reached a 6.8 percent market share, being closely followed by Ford, with 8,780 units sold and a 6.7 percent market share. Some 16,678 commercial vehicles were sold in 2009, down 65.9 percent from the 48,875 units sold in 2008 .

\section{Conclusions}

It may seem superfluous to say once more that the auto market is a very important chain in the European economic mechanism. Nevertheless, as we seen, is a sector extremely vulnerable to the present turmoil. This is a fact well known by the European Organisms that are also admitting the great growth potential of this economic sector. These are only some of the reasons for creating special institutions that assure the proper conditions for the development of the auto market and the proper implementation of the competition rules.

However the figures show that after a blooming period, the crisis hit very hard the automotive market and once more confirmed the paradigm that "desperate times call for desperate measures" that the European Commission is trying to take.

\section{References:}

1. D.Allen, Competition Policy: Policing the Single Market (in H. Wallace and W. Wallace-eds., Policy-Making in the European Union,) Oxford University Press, 1996

2. Commission of the European Communities (2009), European Industry in a changing world, Updated sectorial 2009, Brussels, 30.7.2009 SEC(2009)

3. Edward M. Graham, J.D. Richardson (1997), Global Competition Policy, Institute for International Economics

4. Massimo Motta (2004), Competition Policy, Theory and Practice, Cambridge University Press

5. Roger J. Van den Bergh, Peter D. Camesasca (2001), European Competition Law and Economics- A comparative perspective, Intersentia-Hart

6. World Bank, OECD (1999), A framework for the design and the implementation of competition law and policy

7. Leonard Waverman, W. S. Comanor, Akita Goto (2002), Competition Policy in the global economy: Modalities of cooperation, Routledge 